\title{
Adenosine modulation of potassium currents in postganglionic neurones of cultured avian ciliary ganglia
}

\author{
${ }^{1}$ Max R. Bennett, Rod Kerr \& Kerry Nichol \\ The Neurobiology Research Centre, University of Sydney, Sydney, N.S.W. 2006, Australia
}

1 Potassium currents in cultured postganglionic neurones of avian ciliary ganglia were analysed under whole-cell voltage clamp and their modulation by adenosine determined.

2 In the presence of tetrodotoxin $(200 \mathrm{nM})$, and with moderate holding potentials $(\mathrm{Vh}=-40 \mathrm{mV})$, the steady-state current-voltage $(I / V)$ curve was $\mathrm{N}$-shaped over the range from $-70 \mathrm{mV}$ to $+155 \mathrm{mV}$. CsCl (1 M) blocked the current, indicating that it was carried by $\mathrm{K}^{+}$. If $\mathrm{Ca}^{2+}$ influx was blocked by $\mathrm{CdCl}_{2}$ $(500 \mu \mathrm{M})$ then the outward current was reduced and the $\mathrm{N}$-shaped $I-V$ curve lost, indicating the presence of a calcium-activated potassium current $\left(I_{\mathbf{K}\left(\mathbf{C}_{\mathbf{a}}\right)}\right)$; the remaining current, due to the delayed rectifier $\left(I_{\mathbf{K}}\right)$, increased with depolarization up to about a conductance of $10 \mathrm{nS}$ near $+50 \mathrm{mV}$. This $I_{\mathrm{K}}$ was $50 \%$ activated at about $+20 \mathrm{mV}$ and $50 \%$ inactivated at about $-50 \mathrm{mV}$. Adenosine $(10 \mu \mathrm{M})$ had similar affects on the $\mathrm{N}$-shaped $I / V$ curve as did $\mathrm{CdCl}_{2}$, indicating that it blocked $I_{\mathbf{K}\left(\mathrm{Ca}_{2}\right)}$. However, adenosine had little affect on the steady-state current in the presence of $\mathrm{CdCl}_{2}$, indicating that it did not much affect $I_{\mathrm{K}}$.

3 In the presence of tetrodotoxin (200 nM), a large inward current occurred for large hyperpolarizations from a $\mathrm{Vh}=-50 \mathrm{mV}$. This inward rectifying current $\left(I_{\mathrm{IR}}\right)$ had a reversal potential near $\mathrm{E}_{\mathrm{K}}$ and showed $50 \%$ activation at about $-130 \mathrm{mV}$. Adenosine $(10 \mu \mathrm{M})$ reduced $I_{\mathrm{IR}}$, by as much as $50 \%$ at large hyperpolarizations beyond $-80 \mathrm{mV}$.

4 Relaxations of the outward current on hyperpolarization from $\mathrm{Vh}=-30 \mathrm{mV}$ were blocked by carbachol $(10 \mu \mathrm{M})$, had a reversal potential near $\mathrm{E}_{\mathrm{K}}$, and an $I / V$ curve typical of $I_{\mathrm{M}}$ currents. These currents were little affected by adenosine $(10 \mu \mathrm{M})$.

5 A fast transient outward current, due to depolarizing pulses from a large $\mathrm{Vh}=-110 \mathrm{mV}$ was observed in the presence of tetrodotoxin $(200 \mathrm{nM})$. This had the characteristics of an $I_{\mathrm{A}}$ current as it could be blocked with 4-aminopyridine $(5 \mathrm{mM})$ and was $50 \%$ activated at about $-20 \mathrm{mV}$ and $50 \%$ inactivated at about $-94 \mathrm{mV}$. The $I_{\mathrm{A}}$ current was reduced by $42 \%$ at a depolarization of $-20 \mathrm{mV}$ by adenosine $(10 \mu \mathrm{M})$.

6 Many neurones possessed a fast transient outward current that was blocked by tetrodotoxin ( $200 \mathrm{~nm})$. This current could be blocked with 4-aminopyridine $(5 \mathrm{mM})$; it therefore has the characteristics of a sodium-activated potassium current $\left(I_{\mathrm{K}(\mathrm{Na})}\right)$. This $I_{\mathrm{K}(\mathrm{Na})}$ was unaffected by adenosine $(10 \mu \mathrm{M})$.

7 These results are discussed in relation to the role of adenosine in blocking $\mathrm{Ca}^{2+}$ channels and thereby modifying calcium-dependent components of $\mathrm{K}^{+}$currents.

Keywords: Synapse; potassium current; ciliary neurones; adenosine; postganglionic neurones; $\mathrm{Ca}^{2+}$ channels

\section{Introduction}

Endogenous adenosine modulates secretion at synapses (Phillis \& Wu, 1981), by acting as an autoinhibitory agent which reduces both the mean quantal content of the synaptic potential and its variance (Ribeiro \& Sebastiao, 1987; Bennett et al., 1991). The avian ciliary ganglion provides an opportunity to elucidate the mechanism of action of adenosine as transmission is modulated by endogenous purine nucleotides at this synapse (Bennett \& Ho, 1991). Furthermore the synapse possesses giant calyciform nerve terminals that are accessible to single electrode voltage clamp (Martin \& Pilar, 1963). Such studies have shown that adenosine hyperpolarizes nerve terminals, suggesting that its action increases the outward potassium currents (Bennett \& Ho, 1991). Adenosine hyperpolarizes atrial cells by activating $I_{M}$ potassium channels via GTP-binding proteins (Kurachi et al., 1986). It also hyperpolarizes both hippocampal and striatal neurones through a Ca-independent $I_{\mathrm{M}}$ type $\mathrm{K}^{+}$channel that requires guanosine 5 '-triphosphate for activation (Trussell \& Jackson, 1987). In addition, adenosine increases a 4-amino pyridine-sensitive potassium current in hippocampal neurones (Gerber et al., 1989). In the present work cultured ciliary neurones have been used to analyse the action of adenosine on the large number of macroscopic $\mathrm{K}^{+}$currents which are found in these neurones.

\footnotetext{
1 Author for correspondence.
}

\section{Methods}

Tissue culture

White leghorn chicks were used for all experiments. Ciliary ganglia from 7-9-day old chick embryos were dissected free in $\mathrm{Ca}^{2+}, \mathrm{Mg}^{2+}$-free Hanks Balanced Salt Solution containing $0.3 \%$ bovine serum albumin (BSA), and incubated at $37^{\circ} \mathrm{C}$ for $30 \mathrm{~min}$. No proteolytic enzymes were used. The supernatant was removed and $1 \mathrm{ml}$ of Dulbecco's Modified Eagles' Media (DMEM, Flow, Sydney) supplemented with $2 \mathrm{~mm}$ glutamine, $1.00 \mathrm{u} \mathrm{ml}^{-1}$ penicillin, $50 \mu \mathrm{g} \mathrm{ml}^{-1}$ streptomycin, $10 \%$ heatinactivated horse serum (CSL) and $2 \%$ chick embryo extract was added. The ganglia were then mechanically dissociated by repeated trituration through a Pasteur pipette. The resultant single cell suspension was plated onto $13 \mathrm{~mm}$ glass coverslips previously coated with poly-L-lysine in 24-well plates (Corning) and maintained at $37^{\circ} \mathrm{C}$ in a $5 \% \mathrm{CO}_{2}$ in air watersaturated atmosphere until required. Neurones were used for whole-cell recording within 12 to $24 \mathrm{~h}$ after plating, when they have few processes. These cells were chosen to minimize difficulties involving spatial non-uniformities of membrane potential arising from inadequate space clamp; if these occurred the results were excluded.

\section{Solutions}

Electrodes for forming gigaohm seals with the cell membranes of ciliary neurones were fabricated from boro-silicate capillary 
tubing and had resistances of 0.5 to $2.0 \mathrm{M} \Omega$ when filled with internal solution (Hamill et al., 1981). For the whole-cell recording presented in this work, the pipette solution consisted of (mM): $\mathrm{KCl} 115, \mathrm{MgCl}_{2}$ 1, HEPES 40, GTP 2, ATP 1 with $\mathrm{KOH}$ added to give a $\mathrm{pH}$ of 7.3. The bathing solution consisted of (mM): $\mathrm{NaCl} 140, \mathrm{KCl} 5, \mathrm{CaCl}_{2} 2, \mathrm{MgCl}_{2} 2$, glucose 10, HEPES 10, tetrodotoxin $200 \mathrm{~nm}$ and $\mathrm{NaOH}$ added to give a $\mathrm{pH}$ of 7.3. Variations on these solutions involved addition of KEGTA to the pipette solution, addition of $\mathrm{CdCl}_{2}$ to the bath solution or omission of tetrodotoxin or $\mathrm{CaCl}_{2}$ from the bath solution. Such changes are noted in the appropriate legends. All experiments were at room temperature, about $21^{\circ} \mathrm{C}$.

\section{Recording}

Whole cell patch clamp techniques were used (Fenwick et al., 1982) to voltage-clamp cells. Prior to forming seals the pipette current due to liquid junction potentials within the electrode and bath was nulled and the pipette capacitance compensated. After establishing a seal, the patch membrane was broken under slight negative pressure by a short $(0.5 \mathrm{~ms}) 1.5 \mathrm{~V}$ pulse. This negative pressure, which delayed the onset of loss of contact with the cytoplasm, was maintained throughout the course of the experiment. Ion currents were recorded via an Axopatch IC amplifier and a labmaster interface on an IBM-AT using pClamp (Axon Instruments) software. Currents filtered at $2 \mathrm{kHz}$, were sampled at 0.5 to $6.7 \mathrm{kHz}$ depending on the duration of the voltage clamp command.

Records presented in the figures have had periods of less than $2 \mathrm{~ms}$ at the onset and offset of the command pulses removed to eliminate spurious points due to incomplete capacitance compensation. If there were indications of incomplete voltage clamping, due to inadequate space clamp, then the results were rejected. Voltage-clamp control was determined according to several criteria: firstly, smooth voltagedependent current activation; secondly, lack of excessive delay in onset of current; thirdly, onset and offset kinetics that were dependent on voltage but not on the amplitude of the current. Isopotentiality of the neuronal membrane was determined by testing the exponentiality of the capactive transient.

\section{Adenosine application}

Micropipettes with tip diameters of about $10 \mu \mathrm{m}$ were used to deliver the drug solutions. The pipettes were filled with bath solution together with adenosine to a final concentration of $10 \mu \mathrm{M}$ to $15 \mu \mathrm{M}$. The tips of the micropipettes were positioned 20 to $50 \mu \mathrm{m}$ from the neurone cell body and adenosine pres-

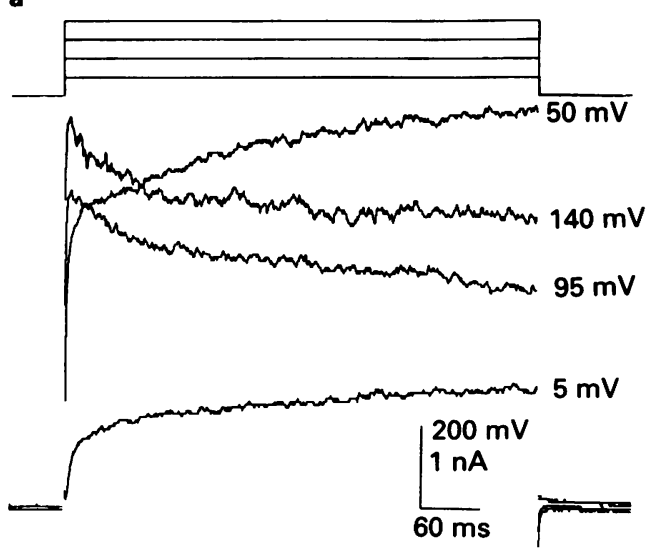

sure ejected at $5 \mathrm{kPa}$. During application of the adenosine, currents were evoked every $20 \mathrm{~s}$. Neurones were required to show stable current magnitudes for at least $2 \mathrm{~min}$ before application of the adenosine, otherwise the results were rejected.

\section{Drugs}

The drugs used and obtained from Sigma, were: tetrodotoxin, tetraethylammonium chloride, adenosine and 8phenyltheophylline.

\section{Statistical analysis}

Values are expressed as mean \pm s.e. and $n$ indicates the number of neurones.

\section{Results}

The delayed rectifier $\left(\mathrm{I}_{\mathrm{K}}\right)$ and calcium-activated potassium currents $\left(\mathrm{I}_{K(\mathrm{Ca})}\right)$ : effects of adenosine

Depolarizing voltage-command steps of $470 \mathrm{~ms}$ duration from a holding potential $(\mathrm{Vh})$ of $-40 \mathrm{mV}$ gave outward currents of the kind shown in Figure 1a in all cultured ciliary neurones studied ( $n=20$ neurones). The current at the end of the command step increases up to depolarizations of about $+60 \mathrm{mV}$; thereafter the current declines to reach a minimum at about $+100 \mathrm{mV}$ from which it increases again (Figure 1b). This N-shaped current-voltage curve is typical of that for neurones in which a large component of the outward current passes through calcium-activated potassium channels $\left(I_{\left.\mathbf{K}_{(\mathbf{C a}}\right)}\right)$ : as $I_{\mathbf{K}\left(\mathbf{C}_{\mathbf{a}}\right)}$ decreases markedly for depolarizing commands close to the calcium equilibrium potential, a minimum is reached near this potential on the current-voltage relationship (see for example Hermann \& Gorman, 1981; Galvan \& Sedlmeir, 1984).

The delayed rectifier currents $\left(I_{\mathrm{K}}\right)$ were separated from $I_{\mathrm{K}\left(\mathrm{C}_{\mathbf{a}}\right)}$ by blocking the influx of $\mathrm{Ca}^{2+}$ ions with $500 \mu \mathrm{M} \mathrm{Cd}{ }^{2+}$. Figure 2a shows that most of the outward current was blocked by the addition of $\mathrm{Cd}^{2+}$, indicating that most of this current is carried by $I_{\mathrm{K}(\mathrm{Ca})}$. The current-voltage relation for the $\mathrm{Cd}^{2+}$ sensitive current and the $\mathrm{Cd}^{2+}$-insensitive current (Figure $2 \mathrm{~b}$ ) show that the $\mathrm{Cd}^{2+}$-sensitive current declines to less than $1 \mathrm{nA}$ about the expected calcium-equilibrium potential (near $+100 \mathrm{mV}$ ) whereas the $\mathrm{Cd}^{2+}$-insensitive current increases continually with depolarization. If the $\mathrm{Cd}^{2+}$-insensitive current is taken as $I_{K}$, then the steady-state conductance for the $I_{\mathrm{K}}$ channel increased from $-50 \mathrm{mV}$ depolarization to reach a value of about $8.5 \mathrm{nS}( \pm 1.4 \mathrm{nS}, n=3)$ at $+50 \mathrm{mV}$ (Figure 2c).

Figure 1 (a) Shows a set of voltage-clamp currents for a ciliary neurone during command pulses at $470 \mathrm{~ms}$ duration to the different levels indicated by the rectangular traces; the holding potential was $-40 \mathrm{mV}$; (b) shows the current-voltage relation determined from the currents at the end of the traces for the neurone in (a). 


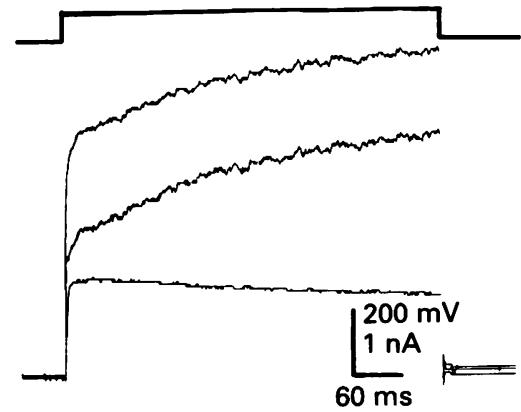

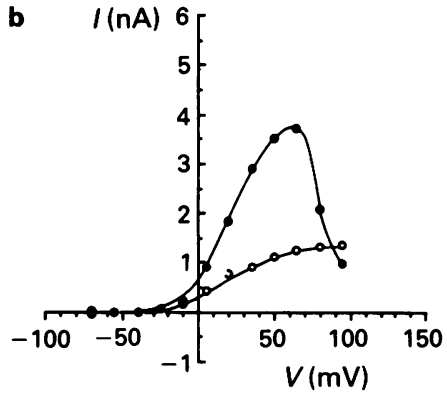

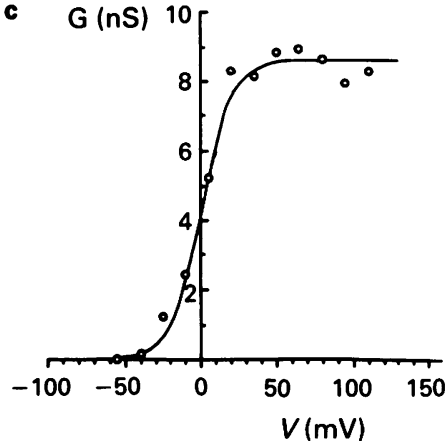

Figure 2 Separation of the total delayed outward current in a ciliary neurone into delayed rectifier $\left(I_{\mathbb{K}}\right)$ and calcium-activated potassium $\left(I_{\mathbf{K}\left(\mathrm{C}_{2}\right)}\right)$ components: (a) shows the voltage-clamp currents for a ciliary neurone during a depolarizing command pulse of $470 \mathrm{~ms}$ duration (indicated by the rectangular trace) before (upper trace) and during the application of $\mathrm{Cd}^{2+}(500 \mu \mathrm{M}$ : lower trace) by pressure ejection; holding potential is $-40 \mathrm{mV}$; the remaining (middle) trace gives the difference between the currents before and after $\mathrm{Cd}^{2+}$; (b) gives the current-voltage relation for the current remaining after addition of $\mathrm{Cd}^{2+}\left(\mathrm{O}, I_{\mathrm{v}}\right)$ as well as the current-voltage relation for the current due to subtracting that remaining after $\mathrm{Cd}^{2+}$ from the control current $\left(\mathbf{O} ; I_{\mathrm{k}\left(\mathrm{r}_{\mathrm{a}}\right)}\right)$. In (c) the steady-state conductance $\left(\mathrm{G}_{\mathrm{k}}\right)$ for the $I_{\mathrm{K}}$ in (b) according to $\mathrm{G}_{\mathrm{k}}=I_{\mathrm{K}}\left(\mathrm{V}-V_{\mathrm{K}}\right)$, where $V_{\mathrm{K}}=-75 \mathrm{mV}$ is shown; the curve has been drawn according

to $G_{k}=G_{k}\left\{1+\exp \frac{Z e}{k T}(V o-V)\right\}^{-1}$ in which $G_{k}=8.6 n S,: V o=0 m V, Z=2.5, \frac{Z e}{k T}=\frac{Z f}{R T}=0.1$.

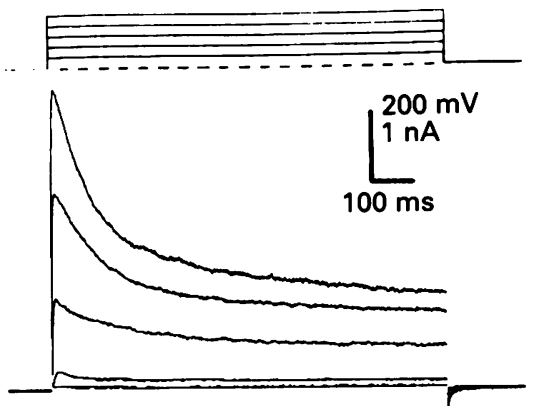

b

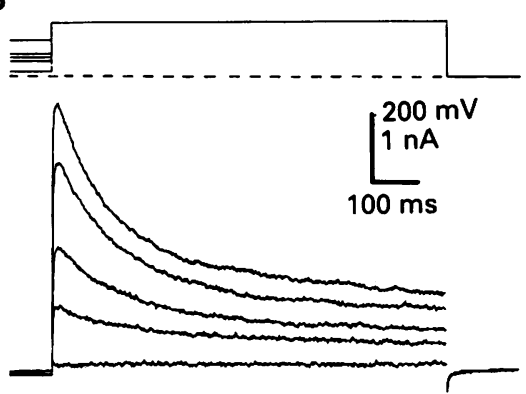

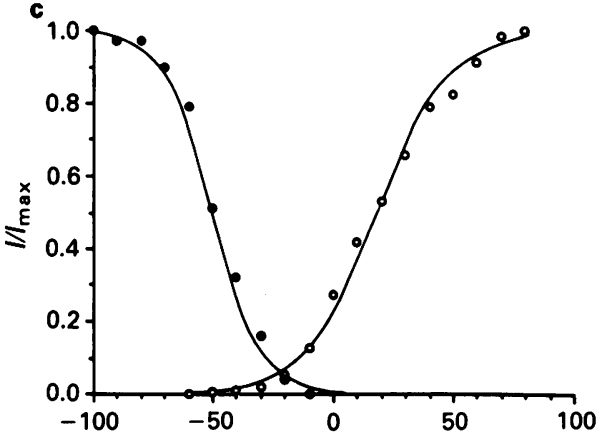

Figure 3 Activation and inactivation of the delayed rectifier current $\left(I_{k}\right)$ : (a) gives a set of voltage-clamp currents for the same ciliary neurone during depolarizing commands indicated by the rectangular traces from a holding potential of $-80 \mathrm{mV}$; (b) shows a set of voltage-clamp currents during a depolarizing command to $+50 \mathrm{mV}$ from different holding potentials (indicated by the rectangular traces). In (c) the activation curve for the steady-state current (at $940 \mathrm{~ms}$ ) for this neurone (O; holding potential $\mathrm{Vh}=-80 \mathrm{mV})$ is shown, derived from the results in (a), as well as an inactivation curve ( $)$; depolarization to $+50 \mathrm{mV})$ derived from the results in (b); the graph shows the respective current values $(I)$ each normalized to their maximum saturated values $\left(I_{\text {mar }}\right)$. The inactivation curve has been drawn according to $h=\left(1+\exp (\mathrm{V}-\mathrm{Vh}) / \mathrm{V}^{*}\right)^{-1}$ in which $\mathrm{Vh}$ (the potential for $\mathrm{h}$ of 0.5$)$ is $-50 \mathrm{mV}$ and $\mathrm{V}^{*}$ is $+10 \mathrm{mV}$. The activation curve has been drawn according to $h=\left(1+\exp (\mathrm{Vh}-\mathrm{V}) / \mathrm{V}^{*}\right)^{-1}$ in which $\mathrm{Vh}$ is $+17 \mathrm{mV}$ and $\mathrm{V}^{*}$ is $+15 \mathrm{mV}$. $\mathrm{Cd}^{2+}$ $(200 \mu \mathrm{M})$ present throughout to block $I_{\mathrm{K}(\mathrm{Ca})}$. There was no $\mathrm{Ca}^{2+}$ in the bath solution and KEGTA (10mM) substituted for $\mathrm{KCl}$ $(10 \mathrm{mM})$ in the pipette solution.

a

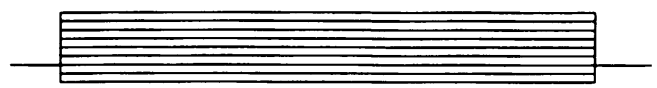

b

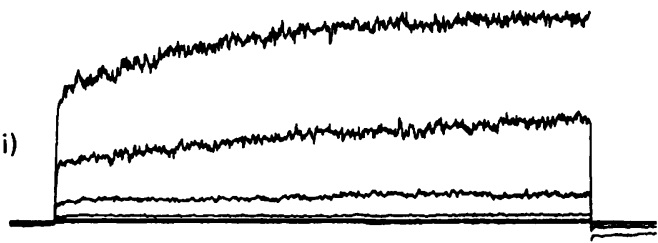

(ii)
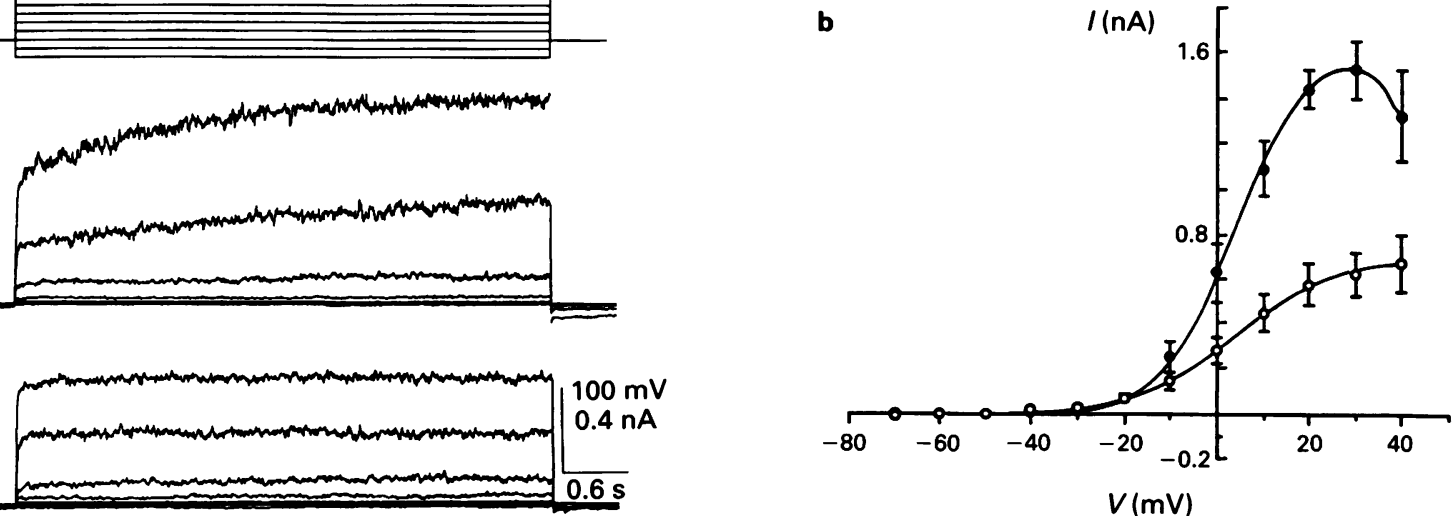

Figure 4 Effects of adenosine on the calcium-activated potassium current $I_{\mathbf{K}\left(\mathrm{C}_{\mathbf{a}}\right)}$. In (a) is shown a set of voltage-clamp currents in a ciliary neurone during command pulses of $5 \mathrm{~s}$ duration to the different levels indicated by the rectangular traces from a holding potential of $-50 \mathrm{mV}$ both (i) before and (ii) after the addition of adenosine (15 $\mu \mathrm{M})$ to the bath. In (b) are shown the current-voltage relation determined from the currents at the end of the traces in (a) for control $(O)$ and in the presence of adenosine $(O)$; vertical bars give \pm s.e.mean $(n=5$ cells $)$. 
a

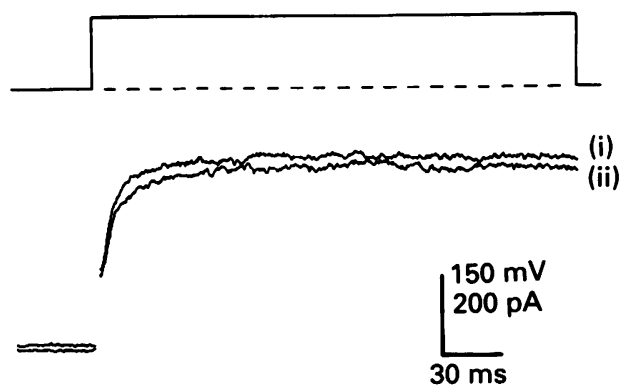

b

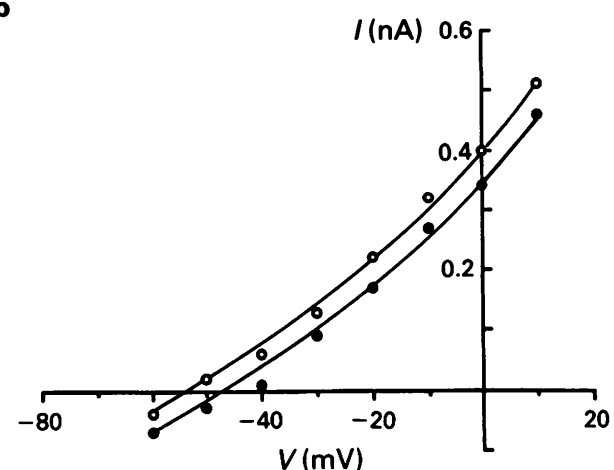

Figure 5 Effects of adenosine on the delayed rectifier current $I_{\mathrm{K}}$. In (a) are shown voltage-clamp currents in a ciliary neurone during depolarizing command pulses of $250 \mathrm{~ms}$ duration to $-20 \mathrm{mV}$ from a holding potential of $-110 \mathrm{mV}$ before (ii) and during (i) the addition of adenosine $(10 \mu \mathrm{M})$ by pressure ejection; (b) shows the current-voltage relation determined from the currents at the end of the traces like those for the cell in (a) for control $(O)$ and in the presence of adenosine $(O)$. There was no $\mathrm{Ca}^{2+}$ in the bath solution and EGTA (10 mM) substituted for $\mathrm{KCl}(10 \mathrm{~mm})$ in the pipette solution.

a
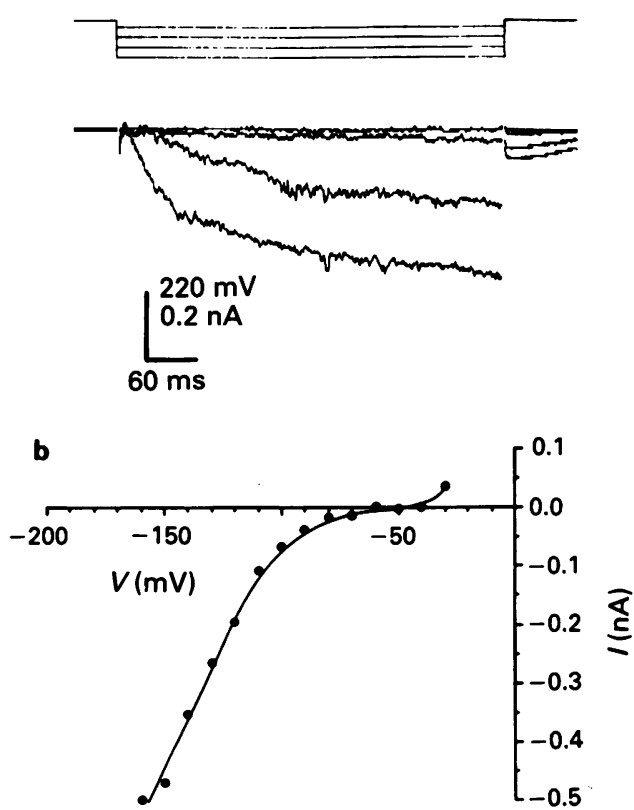

c

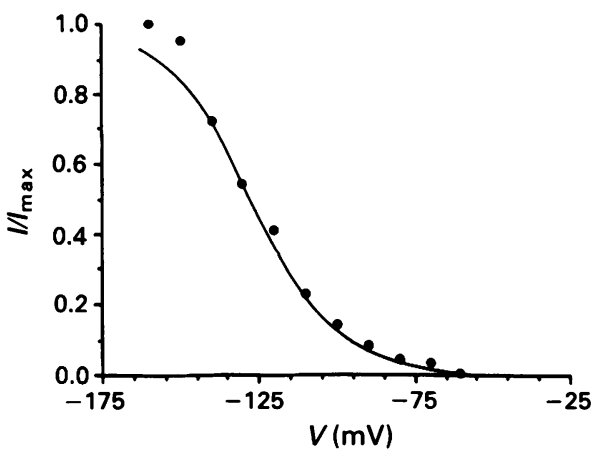

Figure 6 The presence of inward rectifier currents $\left(I_{\mathrm{IR}}\right)$ in ciliary neurones; (a) a set of voltage-clamp currents in a ciliary neurone during hyperpolarizing command pulses of $470 \mathrm{~ms}$ duration to the different levels $(\mathrm{mV})$ indicated by the rectangular traces; the holding potential was $-50 \mathrm{mV}$. The current-voltage relation is shown in (b) determined from the currents at the end of the traces for the neurone in (a). The activation curve for the steady-state current derived from the results in (a) is shown in (c); the graph shows the respective current values $(I)$ each normalized to their maximum saturated values $\left(I_{\max }\right)$; the curve has been drawn according to $h=\left(1+\exp (V-V h) / V^{*}\right)^{-1}$ in which $\mathrm{Vh}$ is $-127 \mathrm{mV}$ and $\mathrm{V}^{*}$ is $=14 \mathrm{mV}$. $\mathrm{CdCl}_{2}(200 \mu \mathrm{M})$ but no $\mathrm{Ca}^{2+}$ was present in the bath solution; KEGTA $(10 \mathrm{~mm})$ substituted for $\mathrm{KCl}$ $(10 \mathrm{mM})$ in the pipette solution.
The activation and inactivation of the steady-state $\mathrm{Cd}^{2+}$. insensitive current, $I_{\mathrm{K}}$ was determined for a cell in which large currents were generated (Figure 3a). Successively larger command depolarizations from a holding potential of $-80 \mathrm{mV}$ gave successively larger currents up to about $+70 \mathrm{mV}$ when saturation was reached; $50 \%$ activation occurred at about $+20 \mathrm{mV}( \pm 6 \mathrm{mV}, n=3)$ (Figure 3c). An inactivation curve was also determined for this steady-state current by using a depolarizing command of $+50 \mathrm{mV}$ from successively more positive holding potentials from $-100 \mathrm{mV}$ (see Figure $3 b$ ). Figure $3 c$ shows that maximum currents are obtained for holding potentials more negative than $-80 \mathrm{mV}$ and that $50 \%$ inactivation occurs at about $-50 \mathrm{mV}( \pm 8 \mathrm{mV}$, $n=3$ ).

Adenosine $(10 \mu \mathrm{M})$ had similar effects on the steady-state current generated by $5 \mathrm{~s}$ depolarizing pulses from moderatesize holding potentials in the 5 neurones studied as did the addition of $\mathrm{Cd}^{2+}$ (compare Figure 4a with 2a). Thus the slow increase in outward current in about the first second following

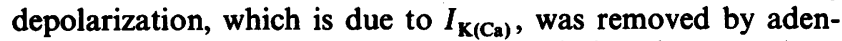
osine (Figure 4b). The current-voltage relation then reverts to that for $I_{K}$ in the presence of adenosine and is, therefore, similar to that in the presence of $\mathrm{Cd}^{2+}$ (compare Figure 4 current-voltage relation with that in Figure 2b). Adenosine had very little effect, if any, on the delayed rectifier, $I_{\mathrm{K}}$ (Figure $5 \mathrm{a})$; this current was increased by, at the most, $40 \mathrm{pA}$ $( \pm 10 \mathrm{pA}, n=5)$ over the voltage range from $-60 \mathrm{mV}$ to $+10 \mathrm{mV}$ (Figure $5 \mathrm{~b}$ ).

Inward rectifier and carbachol-sensitive potassium currents: effects of adenosine

Large hyperpolarizing command voltages from a $\mathrm{Vh}$ of $-50 \mathrm{mV}$ gave very large inward currents (Figure 6a), indicating the existence of an anomalous inward potassium rectifier $\left(I_{\mathrm{IR}}\right)$ in all neurones studied. The current-voltage curves for this channel showed a steep rise in the inward current for hyperpolarizations beyond about $-90 \mathrm{mV}$ (Figure 6b). Extrapolation of the linear part of this curve intersected the voltage axis at about the potassium reversal potential (Figure 6b). An activation curve for this current showed that $50 \%$ activation occurred at $-127 \mathrm{mV}( \pm 20 \mathrm{mV}, n=4)$ (Figure 6c). Adenosine decreases the currents through the inward rectifier (Figure 7a) by amounts which increase with hyperpolarization in the 4 neurones examined (Figure $7 b$ ), so that at about $-100 \mathrm{mV}$ over $50 \%$ of the current has been reduced.

Potassium currents that are blocked by the addition of carbachol $(10 \mu \mathrm{M})$ were also present in all ciliary neurones (Figure 8a). These $I_{M}$ currents can be observed as outward relaxations during hyperpolarizing steps from a holding potential of about $-30 \mathrm{mV}$ (Figure $8 \mathrm{a}$ ). The $I_{M}$ current, measured as the 
a
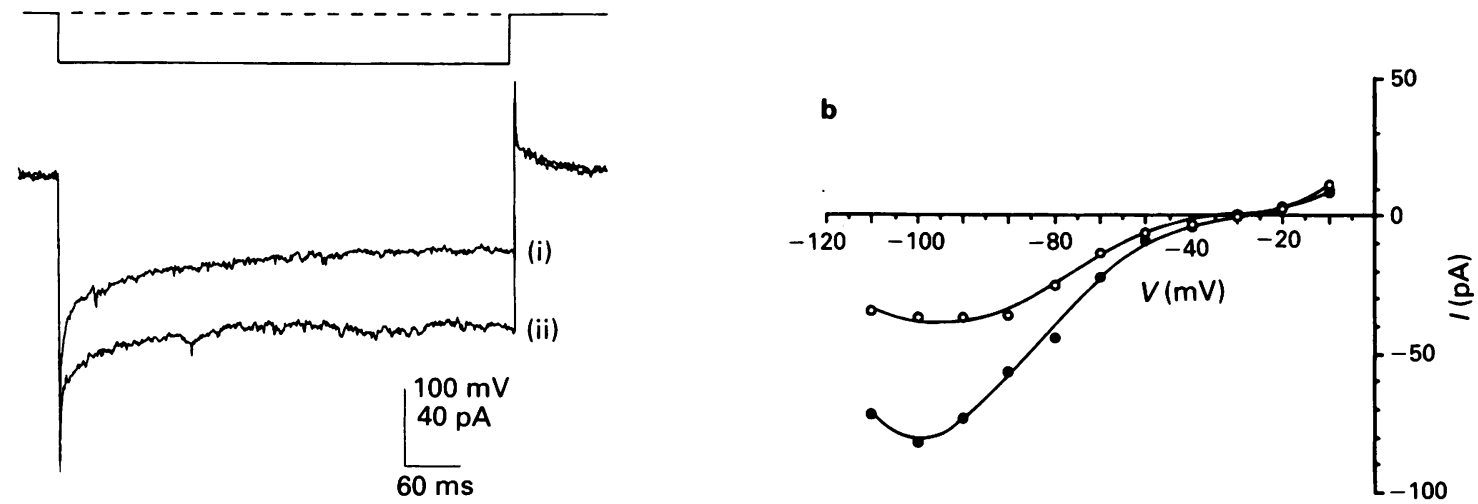

Figure 7 Effects of adenosine on the inward rectifier current $I_{\mathbb{R}}$ : (a) shows voltage-clamp currents during hyperpolarizing command pulses of $490 \mathrm{~ms}$ duration to $-90 \mathrm{mV}$ from a holding potential of $-30 \mathrm{mV}$ before (ii) and during (i) the addition of adenosine (10 $\mu \mathrm{M})$ by pressure injection. The current-voltage relation is shown in (b) determined from the currents at the end of the traces like those for the cell in (a) for control (O) and in the presence of adenosine (O). There was no $\mathrm{Ca}^{2+}$ in the bath solution and KEGTA (10 mM) substituted for $\mathrm{KCl}(10 \mathrm{~mm})$ in the pipette solution.

difference between the initial current $\left(I_{\text {in }}\right)$ and steady-state current $\left(I_{\text {ss }}\right)$ during the hyperpolarizing steps, is relatively unaffected by adenosine ( $n=4$ neurones; Figure $8 \mathrm{~b})$.

\section{Transient $\mathrm{I}_{A}$ and sodium-activated potassium currents: effects of adenosine}

In the presence of tetrodotoxin (200 nM), an early transient outward current generated by depolarizing pulses to about $-35 \mathrm{mV}$ from large holding potentials of about $-110 \mathrm{mV}$ is observed in some cells ( 8 out of 13 neurones; Figure $9 a$ ). This current has the inactivation characteristics of the $I_{\mathrm{A}}$ current (Figure $9 \mathrm{~b}$ ) and is blocked by 4-aminopyridine (Figure 9a). Adenosine $(10 \mu \mathrm{M})$ decreased this current by $42 \%( \pm 8 \%$, $n=5$; Figure 9c). Another early transient outward current can also be observed in some cells ( 7 out of 13 neurones) but only in the absence of tetrodotoxin (Figure 10). This transient was eliminated by 4-aminopyridine. Adenosine had no affect on this sodium activated potassium current $\left(I_{\mathbf{K}(\mathrm{Na})}\right)$ in the 7 neurones in which it was observed.

\section{Discussion}

This work shows that cultured postganglionic neurones from nine-day embryonic avian ciliary ganglia possess a large number of different potassium channel types. The $\mathrm{N}$-shaped current-voltage curve for the quasi steady-state current observed at depolarizations from a moderate holding potential after about $500 \mathrm{~ms}$ was due to co-activation of two different potassium currents, as is the case in rat sympathetic neurones (Galvan \& Sedlmeir, 1984) and molluscan neurones (Hermann \& German, 1981). One of these was a delayed rectifier current $\left(I_{\mathrm{K}}\right)$, having similar characteristics to that of $I_{\mathrm{K}}$ in sympathetic neurones (Galvan \& Seldmeir, 1984), which inactivates over seconds. The other component of the N-shaped current-voltage curve was due to a calcium-activated potassium channel $\left(I_{\mathrm{K}(\mathrm{Ca})}\right)$, as it could be removed by blocking the inward flux of calcium ions with $\mathrm{CdCl}_{2}$. This current had similar characteristics to those of $I_{\mathbf{K}(\mathrm{Ca})}$ in bullfrog sympathetic ganglia, in that it activated soon after a depolarizing command (Lancaster \& Pennefather, 1987). The channels responsible for $I_{\mathbf{K}\left(\mathrm{Ca}_{\mathrm{a}}\right)}$ have been identified directly in ciliary neurones by patch-clamp methods (Gardner, 1986), as $\mathrm{BK}^{+}$or maxi-K ${ }^{+}$channels (Latorre et al., 1989) and have a large conductance $(193 \mathrm{pS})$ as well as an absolute requirement for $\left[\mathrm{Ca}^{2+}\right]_{\mathrm{i}}$. Adenosine considerably reduces $I_{\mathbf{K}(\mathrm{Ca})}$, probably as a consequence of reducing the inward flux of calcium ions in the same way as adenosine reduces $I_{\mathbf{K}\left(\mathrm{C}_{\mathbf{a}}\right)}$ in dorsal root ganglion cells (Scott \& Dolphin, 1987). $I_{\mathbf{K}\left(\mathrm{C}_{\mathbf{a}}\right)}$ contributes significantly to the after-hyperpolarization of the action potential in hippocampal neurones (Wong \& Prince, 1981) and to the repolari-

a
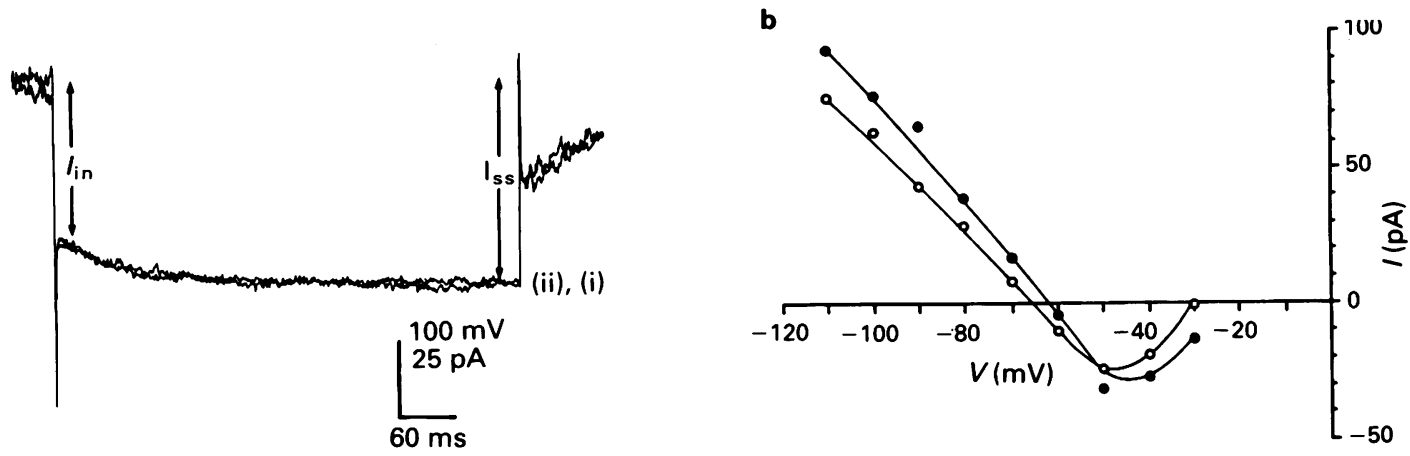

Figure 8 Effects of adenosine on the $I_{M}$ current: (a) shows voltage-clamp currents during hyperpolarizing command pulses of $490 \mathrm{~m}$ duration to $-50 \mathrm{mV}$ from a holding potential of $-30 \mathrm{mV}$ before (ii) and during (i) the addition of adenosine (10 $\mu \mathrm{M})$ by pressure ejection. In (b) is shown the current-voltage relation determined from the $I_{M}$ currents measured as the slow relaxation at the beginning of the pulse $\left(I_{\mathrm{SS}}-I_{\text {in }}\right) ;(O)$ control $I_{M}$ and $(O) I_{M}$ in the presence of adenosine. There was no $\mathrm{Ca}^{2+}$ in the bath solution and EGTA $(10 \mathrm{mM})$ substituted for $\mathrm{KCl}(10 \mathrm{mM})$ in the pipette solution. 
a

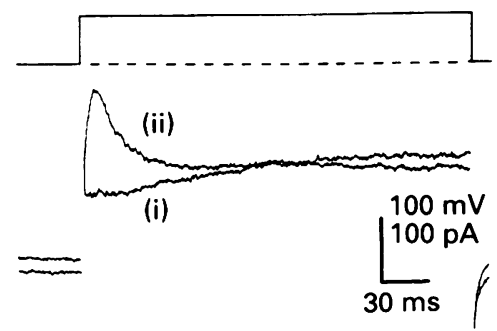

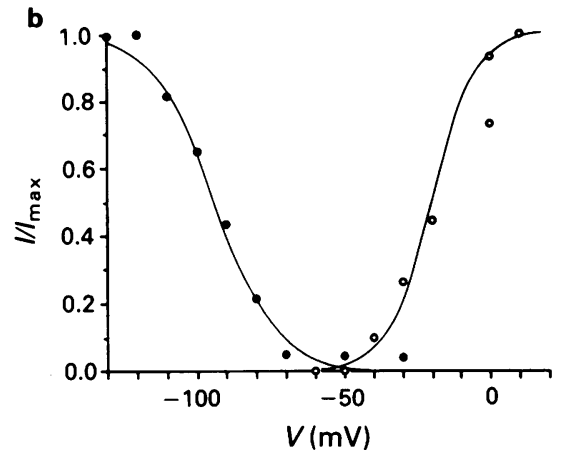

C

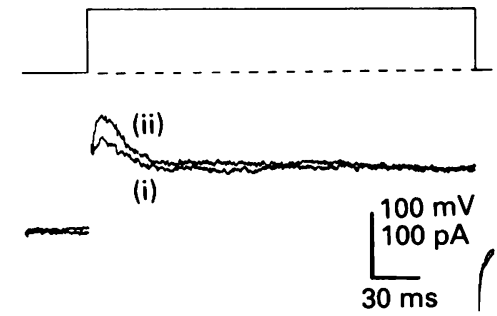

Figure 9 Effects of adenosine on the $I_{\text {A }}$ current. In (a) are shown voltage-clamp currents during depolarizing command pulses of $350 \mathrm{~ms}$ duration to $-35 \mathrm{mV}$ from a holding potential of $-110 \mathrm{mV}$ before (ii) and during (i) the addition of 4-aminopyridine (5 mM) by pressure ejection. Inactivation and activation curves are shown in (b) for the fast transient current derived from results for the cell in (a); the activation graph $(O)$ shows the respective current values $(I)$ each normalized to their maximum saturated values $\left(I_{\text {max }}\right)$; the curve has been drawn according to $h=\left(1+\exp (\mathrm{Vh}-\mathrm{Vh}) / \mathrm{V}^{*}\right)^{-1}$ in which $\mathrm{Vh}$ is $-94 \mathrm{mV}$ and $\mathrm{V}^{*}$ is $+10 \mathrm{mV}$; the activation graph (O) shows the respective current values $(I)$ each normalized to their maximum saturated values $\left(I_{\max }\right)$; the curve has been drawn according to $\mathrm{h}=\left(1=\exp (\mathrm{Vh}-\mathrm{V}) / \mathrm{V}^{*}\right)^{-1}$ in which $\mathrm{Vh}$ is $-20 \mathrm{mV}$ and $\mathrm{V}^{*}$ is $+7.5 \mathrm{mV}$. In (c) are shown voltage-clamp currents during depolarizing command pulses of $300 \mathrm{~ms}$ duration to $-20 \mathrm{mV}$ from a holding potential of $-120 \mathrm{mV}$ before (ii) and after (i) the addition of adenosine $(10 \mu \mathrm{M})$ by pressure ejection. There was no $\mathrm{Ca}^{2+}$ in the bath solution and EGTA (10 mM) substituted for $\mathrm{KCl}$ $(10 \mathrm{mM})$ in the pipette solution.

zation of the action potential in sympathetic neurones (Lancaster \& Pennefather, 1987). The after-hyperpolarization in hippocampal neurones is greatly reduced by noradrenaline acting to block $I_{\mathbf{K}_{(\mathrm{Ca})}}$ (Madison \& Nicoll, 1986; Lancaster \& Adams, 1986), which adenosine might be expected to do on ciliary neurones.

An anomalous or inward rectifying potassium current $\left(I_{\mathrm{IR}}\right)$ is present in all the cultured ciliary neurones becoming activated at hyperpolarizing levels near $-70 \mathrm{mV}$, like that of $I_{\mathrm{IR}}$ in guinea-pig olfactory cortical neurones (Constanti \&

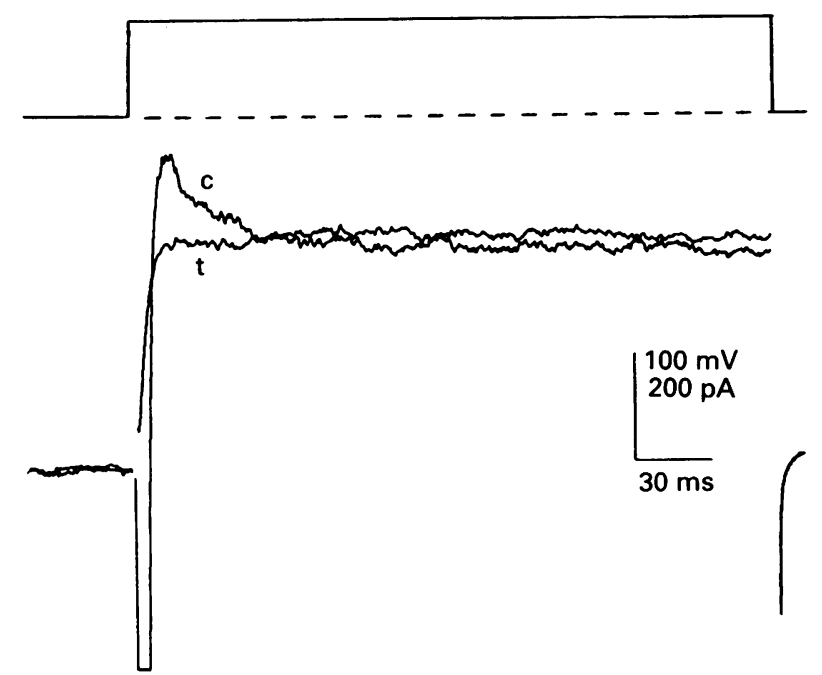

Figure 10 The presence of sodium activated potassium currents $I_{\mathbf{K}(\mathrm{Na})}$ in ciliary neurones. Shown are voltage-clamp currents during depolarizing command pulses of $250 \mathrm{~ms}$ duration to $-20 \mathrm{mV}$ from a holding potential of $110 \mathrm{mV}$ before (c) and during (t) blocking the entry of sodium ions with tetrodotoxin $(200 \mathrm{nM})$ by pressure ejection.

\section{References}

ADAMS, P.R., BROWN, D.A. \& CONSTANTI, A. (1982). Pharmacological inhibition of the M-current. J. Physiol., 332, 223-262.

BENNETT, M.R. \& HO, S. (1991). Probabilistic secretion of quanta from nerve terminals in avian ciliary ganglia modulated by adenosine. J. Physiol., 440, 513-527.

BENNETT, M.R., KARUNANITHI, S. \& LAVIDIS, N.A. (1991). Probabilistic secretion of quanta from nerve terminals in toad (Bufo marinus) muscle modulated by adenosine. J. Physiol., 433, 421434.
Galvan, 1983). Another outward current was revealed during hyperpolarizing steps from a depolarized holding potential. This was distinguishable from the anomalous rectifier by its kinetics and less negative activation range; in addition it was blocked by carbachol and can therefore be identified as an $I_{M}$ current (Adams et al., 1982; Brown et al., 1982). Adenosine reduced $I_{\mathrm{IR}}$ by up to $50 \%$ at large hyperpolarizations. This may be contrasted to the effects of opioids in some neurones, which is to increase $I_{\mathrm{IR}}$ (Loose \& Kelly, 1990). Adenosine had little effect on $I_{\mathrm{M}}$.

Two fast outward transient currents, peaking in less than $5 \mathrm{~ms}$ and then decaying with a time constant of about $20 \mathrm{~ms}$, were also observed for depolarizing steps from large holding potentials. These transients could be distinguished from each other as tetrodotoxin blocked one of them completely, indicating that it was a sodium-activated potassium channel $\left(I_{\mathrm{K}(\mathrm{Na})}\right.$; Hartung, 1985; Dryer et al., 1989). The tetrodotoxininsensitive transient, which was blocked by 4-aminopyridine and had an activation range from $-50 \mathrm{mV}$ to $0 \mathrm{mV}$, had the characteristics of an $I_{\mathrm{A}}$ current, although somewhat faster than the $I_{\mathrm{a}}$ current transients observed in other excitable cells such as hippocampal neurones (Segal et al., 1984; Zbicz \& Weight, 1985). In some neurones only the $I_{\mathrm{K}(\mathrm{Na})}$ was observed and in others only $I_{A}$, whereas a few neurones possessed both $I_{\mathbf{K}(\mathrm{Na})}$ and $I_{\mathrm{A}}$. Adenosine did not affect $I_{\mathbf{K}(\mathrm{Na})}$ but it consistently reduced $I_{\mathrm{A}}$, in much the same way as it does a similar transient potassium current in dorsal root ganglion cells (Scott \& Dolphin, 1987), but in contrast to the effects of adenosine in increasing $I_{\mathrm{A}}$ in hippocampal neurones (Gerber et al., 1989). The rate of action potential firing is regulated by $I_{\mathrm{A}}$ and this rate is higher in tonic-firing sympathetic neurones than in phasic-firing sympathetic neurones (Cassell et al., 1986). It will be of interest to see if adenosine derived from endogenously released adenosine 5 '-triphosphate at preganglionic nerve terminals in ciliary ganglia (Bennett \& Ho, 1990), has a role in modulating impulse traffic in tonic-firing ciliary neurones.

BROWN, D.A., ADAMS, P.R. \& CONSTANTI, A. (1982). Voltage-sensitive $\mathrm{K}$-currents in sympathetic neurons and their modulation by neurotransmitters. J. Autonom. Nerv. Syst., 6, 23-35.

CASSELL, J.F., CLARK, A.L. \& MCLACHLAN, E.M. (1986). Characteristics of phasic and tonic sympathetic ganglion cells of the guineapig. J. Physiol., 372, 457-483.

CONSTANTI, A. \& GALVAN, M. (1983). Fast inward-rectifying current accounts for anomolous rectification in olfactory cortex neurons. J. Physiol., 335, 153-178. 
DRYER, S.E., FUJII, J.T. \& MARTIN, A.R. (1989). A Na ${ }^{+}$-activated K ${ }^{+}$ current in cultured brain stem neurones from chicks. J. Physiol. 410, 283-296.

FENWICK, E.M., MARTY, A. \& NEHER, E. (1982). A patch clamp study of bovine chromaffin cells and of their sensitivity to acetylcholine. J. Physiol., 331, 577-597.

GALVAN, M. \& SEDLMEIR, C. (1984). Outward currents in voltage clamped rat sympathetic neurons. J. Physiol., 356, 115-133.

GARDNER, P.I. (1986). Single channel recordings of three $\mathrm{K}^{+}$-selective currents in cultured chick ciliary ganglion neurons. J. Neurosci., 6 , 2106-2116.

GERBER, U., GREENE, H.L., HAAS, H.L. \& STEVENS, D.R. (1989). Characterization of inhibitions mediated by adenosine in the hippocampus of the rat in vitro. J. Physiol., 417, 567-578.

HAMILL, O.P., MARTY, A., NEHER, E., SAKMANN, G. \& SIGWORTH, F.J. (1981). Improved patch-clamp techniques for high-resolution current recording from cells and cell-free membrane patches. Pflügers Arch., 391, 85-100.

HARTUNG, K. (1985). Potentiation of a transient outward current by $\mathrm{Na}^{+}$influx in crayfish neurones. Pflügers Arch., 404, 41-44.

HERMANN, A. \& GORMAN, A.L.F. (1981). Effects of tetraethylammonium on potassium currents in a molluscan neuron. $J$. Gen. Physiol., 78, 87-110.

KURACHI, Y, NAKAJIMA, T. \& SUGIMOTO, T. (1986). On the mechanism of activation of muscarinic $\mathrm{K}^{+}$channels by adenosine in isolated atrial cells: involvement of GTP-binding proteins. Pflügers Arch., 407, 264-274.

LANCASTER, B. \& ADAMS, P.R. (1986). Calcium-dependent current generating the after-hyperpolarization of hippocampal neurons. $J$. Neurophysiol., 55, 1268-1282.

LANCASTER, B. \& PENNEFATHER, P. (1987). Potassium currents evoked by brief depolarizations in bull-frog sympathetic ganglion cells. J. Physiol., 387, 519-548.
LATORRE, R., OBERHAUSER, A., LABARCA, P. \& ALVAREZ, O. (1989). Varieties of calcium-activated potassium channels. Annu. Rev. Physiol., 51, 385-399.

LOOSE, M.D. \& KELLY, M.J. (1990). Opioids act at $\mu$-receptors to hyperpolarize accurate neurons via an inwardly rectifying potassium conductance. Brain Res., 513, 15-23.

MADISON, D.V. \& NICOLL, R.A. (1986). Actions of noradrenaline recorded intracellularly in rat hippocampal CA1 pyramidal neurones in vitro. J. Physiol., 372, 221-244.

MARTIN, A.R. \& PILAR, G. (1963). Transmission through the ciliary ganglion of the chick. J. Physiol., 168, 464-475.

PHILLIS, J.W. \& WU, P.H. (1981). The role of adenosine and its nucleotides in central synaptic transmission. Prog. Neurobiol., 16, 187239.

RIBEIRO, J.A. \& SEBASTIAO, A.M. (1987). On the role, inactivation and origin of endogenous adenosine at the frog neuromuscular junction. J. Physiol., 384, 371-385.

SCOTT, R.H. \& DOLPHIN, A.C. (1987). Inhibition of calcium currents by an adenosine analogue 2-chloroadenosine. In Topics and Perspectives in Adenosine Research. ed. Gerlach, E. \& Becker, B.F. pp. 549-558. Berlin: Springer-Verlag.

SEGAL, M., ROGAWSKI, M.A. \& BARKER, J.L. (1984). A transient potassium conductance regulates the excitability of cultured hippocampal and spinal neurones. J. Neurosci., 4, 604-609.

TRUSSELL, L.D. \& JACKSON, M.B. (1987). Dependence of an adenosine-activated potassium current on a GTP-binding protein in mammalian central neurons. J. Neurosci., 7, 3306-3316.

WONG, R.K.S. \& PRINCE, D.A. (1981). Afterpotential generation in hippocampal pyramidal cells. J. Neurophysiol., 45, 86-97.

ZBICZ, K.L. \& WEIGHT, F.F. (1985). Transient voltage and calciumdependent outward currents in hippocampal CA3 pyramidal neurons. J. Neurophysiol., 53, 1038-1058.

(Received April 24, 199

Revised June 10,1991

Accepted June 13, 1991 